\title{
RECLASSIFICATION OF CANDIDA GUILLIERMONDII FTI 20037 AS CANDIDA TROPICALIS BASED ON MOLECULAR PHYLOGENETIC ANALYSIS
}

\author{
Luanne Helena Augusto Lima ${ }^{1 *}$; Maria das Graças de Almeida Felipe²; \\ Fernando Araripe Gonçalves Torres ${ }^{1}$ \\ ${ }^{1}$ Departamento de Biologia Celular, Universidade de Brasília, Brasília, DF, Brasil. ${ }^{2}$ Departamento de Biotecnologia, \\ FAENQUIL, Lorena, SP, Brasil.
}

This paper corresponds to an "extended abstract" selected for oral presentation in the $22^{\text {nd }}$ Brazilian Congress of Microbiology, held in Florianópolis, SC, Brasil, in November 17-20, 2003

\begin{abstract}
Yeasts of the genus Candida are of clinical importance and also have many industrial applications, mainly in the food industry. The yeast Candida guilliermondii FTI 20037 has been extensively studied in order to establish a biotechnological process for the production of xylitol. The goal of this study was to verify the taxonomic classification of this strain based on the analysis of rDNA sequences and the xyll gene. DNA fragments from these sequences were amplified by PCR and BLAST analysis revealed strong identity with the corresponding sequences from Candida tropicalis. Based on these results, we propose that $C$. guilliermondii FTI 20037 must be reclassified as C. tropicalis.
\end{abstract}

Key words: Candida guilliermondii, Candida tropicalis, ribosomal DNA, xylitol.

\section{INTRODUCTION}

Yeasts of the genus Candida are ascomycetes generally found in the unicellular form but many species may exhibit hyphal growth. Some yeasts of this genus are involved in important human opportunistic infections. In addition to their clinical importance, these yeasts have many industrial applications, mainly in food industry. Some species are known to produce xylitol, a product of great economic interest due to its anticariogenicity and sweetening properties which have been exploited in the production of foodstuffs, odontological products and pharmaceuticals. Among the xylitol-producing yeasts of this genus, Candida tropicalis and Candida guilliermondii are the most important, with yields above $0.7 \mathrm{~g}$ xylitol/g xylose. Although many Candida species are pathogenic opportunists, the Food and Drug Administration (FDA) has permitted

C. guilliermondii (ATCC 20474) and Candida lipolytica to be used in food for human consumption as Secondary Direct Food Additives in the production of citric acid (5).
The aim of this study was to use a molecular biology approach to verify the classification of xylitol-producing yeast which was originally assigned as $C$. guilliermondii FTI 20037 (1). This approach involved the analysis of two ribosomal DNA sequences commonly used in molecular phylogenetic studies: internal transcribed spacer region (ITS) (6) and the $5^{\prime}$ end of the 28S large-subunit ribosomal DNA gene (5'LSU) (4). In order to expand our phylogenetic analysis we have cloned and sequenced the $x y l 1$ gene which codes for xylose redutase (EC 1.1.1.21), the enzyme that converts xylose to xylitol.

\section{MATERIALS AND METHODS}

\section{Strains and media}

The yeast C. guilliermondii FTI 20037 has been described elsewhere (1). As a control in PCR experiments, we used DNA purified from an isolate of $C$. guilliermondii which was a kind gift of Mônica Damasceno (UFRJ). Yeasts were routinely cultivated on YPD medium (yeast extract $10 \mathrm{~g} / \mathrm{L}$, peptone $20 \mathrm{~g} / \mathrm{L}$, dextrose $20 \mathrm{~g} / \mathrm{L}$ ). 
Escherichia coli DH5a was used as host for molecular cloning procedures. E. coli was cultivated on LB medium (tryptone $10 \mathrm{~g} / \mathrm{L}$, yeast extract $5 \mathrm{~g} / \mathrm{L}, \mathrm{NaCl} 10 \mathrm{~g} / \mathrm{L}$ ) containing ampicillin $(100 \mathrm{mg} / \mathrm{mL})$.

\section{PCRAmplification}

Yeast genomic DNA was prepared by the method described by Burke et al. (2). ITS region was amplified using primers ITS1 and ITS4 according to previously described protocols (6). The 5'LSU region was amplified with primers CTB6 and TW13 according to Haynes et al. (4). Primers used for amplification of xylose reductase gene sequences are listed in Table 1. PCR was carried out in a $25 \mathrm{~mL}$ volume with: $0.25 \mathrm{mM} \mathrm{dNTP}, 3.5 \mathrm{MgCl}_{2}$, $3 \mathrm{mM}$ each primer, $1 \mathrm{X}$ Taq polymerase buffer, $2 \mathrm{U}$ Taq polymerase and $0.5 \mathrm{mg}$ of yeast DNA as template. Reaction mixtures were subjected to 45 amplification cycles, each cycle being: $95^{\circ} \mathrm{C} /$ $1 \mathrm{~min} ; 55^{\circ} \mathrm{C} / 90 \mathrm{~s} ; 72^{\circ} \mathrm{C} / 90 \mathrm{~s}$. Amplicons were resolved by electrophoresis on $1 \%$ agarose gel.

\section{DNA sequencing and analysis}

PCR products were cloned into the commercial vector TOPO (Invitrogen); plasmid DNA was prepared with the Wizard Plus SV Minipreps kit (Promega). Cycle sequencing was performed using the MegaBACE Dye Terminator procedure (Amersham Biosciences) and reactions were analysed in a MegaBACE 1000 automatic sequencer (Amersham Biosciences). Sequences were analysed against GenBank using the BLAST algorithm.

\section{RESULTS AND DISCUSSION}

\section{Amplification of rDNA and xylose reductase DNA sequences}

The ITS and 5'LSU regions from C. guilliermondii FTI 20037 were amplified by PCR yielding fragments with the expected sizes of $524 \mathrm{bp}$ and $640 \mathrm{bp}$, respectively (Fig. 1A). These fragments were cloned, sequenced and BLAST analysis revealed high identity with the corresponding sequences from C. tropicalis (Table 2). In order to further confirm this result we analysed the sequence of the xylose reductase gene which has been previously described for both $C$. guilliermondii and $C$. tropicalis. Primers designed to specifically amplify the $C$.

Table 1. Primers used for amplification of xylose reductase gene sequences.

\begin{tabular}{cc}
\hline Primer & Sequence (5 ->3) \\
\hline 5XRORF & CAGATCTGCTATGTCTATCAAGTTAAA \\
3XRORF & CAGATCTTAGATGAAAGTTGGAATCTT \\
5Xylla & CAGATCTACCATGTCTACTACTCCTAC \\
3Xyl1 & CAGATCTTTAAACAAAGATTGGAATGT \\
5XylInt & TACAGATTATTTGATGGTGCTG \\
3Xyl1Int & GGTTGTTGCAAGTATGGGTG \\
\hline
\end{tabular}

guilliermondii xyll gene (5XRORF/3XRORF) were unable to yield any products when genomic DNA of $C$. guilliermondii FTI 20037 was used as template (Fig. 1B). A new set of primers were then designed based on the $x y l 1$ sequence described for C. tropicalis (Fig. 2) and PCR analysis yielded fragments of the expected sizes (Fig. 1C). The product of primers 5xyl1a/3xyl1 was sequenced and BLAST analysis revealed that it was more related to the $x y l 1$ gene from $C$. tropicalis $(99 \%)$ than to $C$. guillermondii $(77 \%)$ (Table 2).

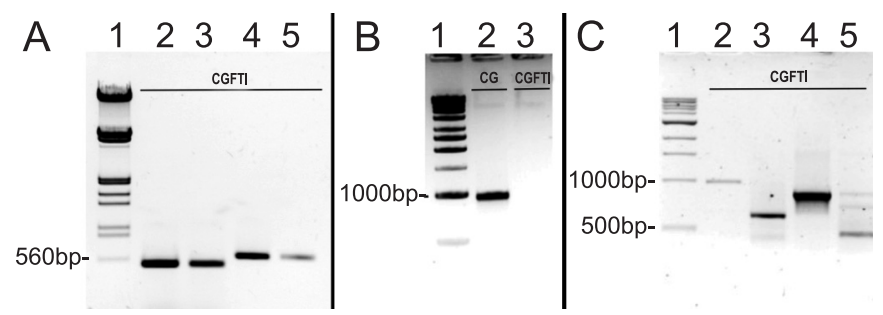

Figure 1. PCR amplification of ITS/ 5 'LSU fragments (A) and $x y l 1$ (B and C). A -Lane 1:EcoRI/HindIII; Lanes 2 and 3: amplification with ITS1 and ITS4; Lanes 4 and 5: amplification with CTB6 and TW13. B - Lane 1: $1 \mathrm{~kb}$ ladder; Lanes 2 and 3 amplification with 5XRORF/3XRORF. C - Lane 1: $1 \mathrm{~kb}$ ladder; Lanes 2 to 5: amplification with 5xyl1a/3xyl1, 5xyl1a/3xyl1 int, 5xyl1 int/3xyl1 and 5xylint/3xyl1 int, respectively. DNA templates: $\mathrm{CG}$ (C. guillermondii - control), CGFTI (C. guillermondii FTI 20037)

Table 2. Summary of the results from BLAST analysis with sequences amplified from C. guilliermondii FTI 20037.

\begin{tabular}{c|lcc}
\hline Sequence & \multicolumn{1}{|c}{ BLAST result } & Identity & E-value \\
\hline \multirow{5}{*}{ ITS } & $\begin{array}{l}\text { Candida tropicalis } \\
\text { (acession \# AF321539) }\end{array}$ & $96 \%$ & 0.0 \\
\cline { 2 - 4 } & $\begin{array}{l}\text { Candida guillermondii } \\
\text { (acession \# AY168784.1) }\end{array}$ & $96 \%$ & $2 \mathrm{e}-85$ \\
\hline \multirow{5}{*}{5 LSU } & $\begin{array}{l}\text { Candida tropicalis } \\
\text { (acession \# AF267497) }\end{array}$ & $86 \%$ & $4 \mathrm{e}-59$ \\
\cline { 2 - 4 } & $\begin{array}{l}\text { Candida tropicalis } \\
\text { (acession \# AB002105.1) }\end{array}$ & $99 \%$ & 0.0 \\
\hline \multirow{3}{*}{ xyl1 } & $\begin{array}{l}\text { Candida guillermondii } \\
\text { (acession \# AF020040.1) }\end{array}$ & $77 \%$ & $3 \mathrm{e}-11$ \\
\cline { 2 - 4 } & $\begin{array}{l}\text { Candida tropicalis } \\
\text { (acession \# AF321539) }\end{array}$ & $96 \%$ & 0.0 \\
\hline
\end{tabular}

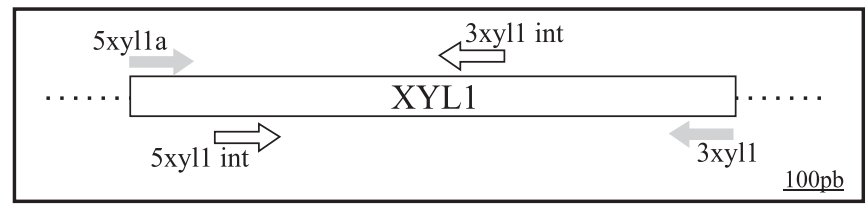

Figure 2. Relative annealing positions of the primers designed for PCR amplification of the xylose reductase ( $x y l 1)$ gene sequences. 
C. guilliermondii FTI 20037 has been extensively studied since 1988 in order to establish a biotechnological process for the production of xylitol. Based on the results presented in this work we propose that

C. guilliermondii FTI 20037 must be classified hereafter as C. tropicalis, an yeast that is closely related to C. guillermondii and which is also known to produce xylitol.

\section{RESUMO}

\section{Reclassificação de Candida guilliermondii FTI 20037 como Candida tropicalis baseada na análise filogenética molecular}

As leveduras do gênero Candida possuem tanto importância clínica como diversas aplicações industriais, principalmente na indústria de alimentos. A levedura Candida guilliermondii FTI 20037 tem sido exaustivamente estudada pois pretende-se utilizá-la no estabelecimento de um processo biotecnológico para a produção de xilitol. O objetivo deste trabalho foi verificar a classificação taxonômica desta levedura por análise de sequências do rDNA e do gene $x y l 1$. Fragmentos correspondentes a estas regiões foram amplificados por PCR e a análise destas sequências por BLAST revelou alta identidade com sequências correspondentes de Candida tropicalis. Estes resultados nos levam a propor que C. guilliermondii FTI 20037 deva ser reclassificada como C. tropicalis.

Palavras-chave: Candida guilliermondii, Candida tropicalis, DNA ribossômico, xilitol.

\section{REFERENCES}

1. Barbosa, M.F.S.; Medeiros, M.B.; Mancilha, I.M.; Schneider, H.; Lee, H. Screening of yeasts for production of xylitol from D-xylose and some factors which affect xylitol yield in Candida guilliermondii. J. Ind. Microbiol., 3:241-251, 1988.

2. Burke, D.; Dawson D.; Stearns, T. Methods in Yeast Genetics: A Cold Spring Harbor Laboratory Course Manual. Cold Spring Harbor Laboratory Press, Peter Sudbery, 2000, 205p.

3. Granström, T. Biotechnological production of xylitol with Candida yeasts. Espoo, 2002, 72p. (Ph.D. Thesis. Department of Chemical Technology. Helsinki University of Technology)

4. Haynes, K.A.; Westerneng, T.J.; Fell, J.W.; Moens, W. Rapid detection and identification of pathogenic fungi by polymerase chain reaction amplification of large subunit ribosomal DNA. J. Med. Vet. Mycol., 33(5):319-325, 1995.

5. Kreger-Van Rij, N.J.W. The yeasts: a taxonomic study. 3rd Edition. Elsevier Science Publishers B.V., Amsterdam, 1984, p. 1082.

6. White, T.J.; Bruns, T.; Lee, S.; Taylor, J. Amplification and direct sequencing of fungal ribosomal RNA genes for phylogenetics. In M. Innis, D. Elfand, J. Sninsky, and T. White (eds.) PCR protocols: a guide to methods and application. Academic Press, San Diego, 1990, p. 315-322. 